\section{Democracy And Information Technologies: Relationship And Development In Uzbekistan}

\author{
Ilyas Tulteev, \\ DSc. Professor, Institute For Advanced Studies Ministry \\ Of Internal Affairs Of The Republic Of Uzbekistan
}

\author{
Eshmukhamad Kadirov, \\ DSc. Professor, Tashkent State Law University, \\ Uzbekistan
}

\author{
G OPEN ACCESS \\ The American Journal of \\ Social Science And \\ Education Innovations \\ JULY 2020 \\ Page No.: 188-194 \\ Volume-II Issue-VII \\ PUBLISHED: 30 JULY 2020 \\ www.usajournalshub.com/inde \\ x.php/tajssei \\ Copyright: Original content \\ from this work may be used \\ under the terms of the \\ Creative Commons Attribution \\ 4.0 licence.
}

\title{
Abstract
}

The article is devoted to the analysis of theoretical and practical aspects of such a phenomenon as the formation of e-democracy in Uzbekistan. The characteristic of the process of introducing information technologies into the system of interaction between the state and citizens is given, the position is argued according to which IT technologies determine the essence of the development of modern democracy. E-democracy is considered in the context of the process of expanding the participation of citizens in the democratic management of state affairs, ensuring the transparency of the activities of state bodies, as well as their interaction with the population.

The article comprehensively reveals the legal essence of e-democracy, proposes the author's approach to the concept of e-democracy. On the basis of the analysis of the conceptual apparatus, the author reveals the peculiarities of the legal regulation of relations in the field of e-democracy, and points out some problems in the development of this phenomenon. Taking into account the assessment of the state of development of edemocracy in the country, the authors made an attempt to consider the prospects for its further development in Uzbekistan.

Keywords: e-democracy, democratic value, interaction between the state and citizens, reform, information and communication technology (ICT), state and public administration, digital democracy.

\section{Introduction}

Today, Uzbekistan is carrying out a large-scale reorganization and modernization of the country, reforming all aspects of public life. The essence of the reforms is their focus on 
achieving a decent level of material well-being and quality of life for the people, ensuring sustainable economic development, and realizing human rights and freedoms. An important area of reform was the creation of institutional and legal foundations for the revitalization of democratic processes based on modern information and communication technologies (ICT).

The modern world is experiencing a boom in ICT development, we have entered the digital age. ICTs are also being actively introduced into the mechanisms for realizing democracy. With this in mind, some experts even talk about a new wave, the "third era" of the development of democracy [1, p.55]. The idea of e-democracy was first proposed by scientists from the United States and Great Britain, implying the use of new information technologies to protect and develop basic democratic values, citizens' participation in the decision-making process by the authorities [2]. This circumstance led to the recognition at the international legal level of the concept of "electronic democracy", understood as the exercise of power by the people using modern information and telecommunication technologies [3].

Unfortunately, in the legal science of Uzbekistan, this phenomenon has not been sufficiently studied [4], although today the process of active implementation of this form (or, in another way, manifestation) of democracy has begun. The innovations include the functioning of the virtual reception room of the President of the country, the government portal gov.uz, the portal of public opinion "Mening Fikrim", the system for assessing the impact of legislative acts (SOVAZ) within the framework of the regulation.uz portal, etc.

\section{The Main Findings And Results}

As a result, in recent years, a fundamentally new model of interaction between the state and citizens using ICT has begun to form. An institutional and legal basis for such interaction has been created, a certain experience has been accumulated. At the same time, there are many problems and reserves here. In fact, we see that practice is significantly ahead of science in this matter, while the latter should not take the position of an outside observer, but in a timely manner investigate the conditions, state and prospects for the development of e-democracy.

The study of foreign experience and scientific literature shows the presence of serious interest in this issue and certain successes in its research. There are a huge number of publications devoted to e-democracy. The category "e-democracy" [5] was recognized, meaning ensuring openness and transparency of state power, active involvement of the population in the process of making political and legal decisions using ICT. Most researchers talk about "electronic democracy" as a promising and effective form of interactive interaction between the state and the people in the modern world.

Considering such concepts as "virtual democracy", "electronic democracy" and "cyberdemocracy", experts [6] argue that digital democracy is not only a new, interactive type of state activity, but also a set of practices for implementing democratic procedures using digital tools, allowing to bring closer, unite state and public administration, without denying, however, the previous traditional forms of citizens' participation in state administration. However, it must be remembered that e-democracy is not a new type of government, it is a new form (as well as a toolkit) for the implementation of democracy.

This is probably why, when defining the content and features of the concept of 
"electronic democracy", researchers express different opinions and approaches. According to Ya.V. Antonov, e-democracy is a legal, technological and managerial structure within which various public law institutions are created and developed (E-government, EParliament, E-government, E-justice) and tools (for example, public discussion of draft regulatory legal acts on the Internet, an electronic forum on significant state and political issues) $[7$, p. 3].

M.S. Grigorieva believes that the concept of "e-democracy is complex and multifaceted", and its essence carries two semantic loads: "democracy" and "electronic ways of its implementation" [8, p. 3]. Other experts argue the thesis about "changing the modern democratic paradigm to a more open one, which promotes the establishment of pluralism, new values, needs, methods and procedures" [9, p. 63]. As A. Yuldashev testifies, public discussion on the Internet allows "to significantly increase the efficiency of work with proposals, and also create conditions for citizens to objectively understand the content and purpose of government decisions, their conscious participation in the conduct of public affairs" [10, p. 24]. In fact, e-democracy is becoming an important tool for realizing democracy, supporting democratic institutions and spreading democratic values in Uzbekistan, it complements and enriches the traditional forms and channels for the implementation of democracy.

In foreign countries, the term "e-democgasu" has become widespread, which means support and strengthening of civil rights and responsibilities in the knowledge and information society. At the same time, the goal of e-democracy is to expand information policy and form an active civic position, increase openness in the activities of public authorities, and support democratic processes. E-democracy covers various forms of citizen participation in the management of state affairs through ICT and includes the population in the processes of managing the country's social development.

Opportunities for the expression and implementation of public interests in public administration increase with the development of ICT, which enhances the impact of edemocracy on all spheres of public life, stimulates the development of new ways and forms of democracy implementation by civil society institutions. Today, the information environment is becoming a multifunctional environment that provides great opportunities for expanding the participation of the population in public administration, the interaction of citizens with public authorities in the provision of public services in electronic form.

So, as of February 7, 2020, the Meningfikrim portal received 3233 collective appeals with the initiative to adopt a regulatory legal act, on which 24,071 user comments were given [12], 3,603,348 appeals were received by the Virtual Reception of the President of the country, of which 3,550,693 considered [13], on the SOVAZ portal discussed 5556 draft normative legal acts [14]. These figures clearly demonstrate the process of expanding the use of interactive ways to implement democracy using ICT and the formation of the institution of e-democracy in the Republic of Uzbekistan.

An analysis of the functioning of the above portals shows that there are a number of problems that need to be addressed. Thus, the results of public discussions, the results of consideration of public initiatives (petitions) submitted to the Meningfikrim portal are not always posted on the portal. The procedure for identifying users has been somewhat complicated. The low computer literacy of users should be noted. The digital divide 
remains between the center and the regions of the republic. Access to the Internet is uneven, the quality of access in rural areas is still at an insufficient level, and there are no effective tools to popularize e-democracy mechanisms. There is no document defining a strategy for the development of e-democracy in Uzbekistan on a long-term basis.

Assessing the state of development of e-democracy in our country, we believe it is possible to draw the following conclusions:

- the introduction of ICT into public practice (including the sphere of public administration), allows us to talk about the formation in Uzbekistan of the primary elements of the institution of "e-democracy", representing a system of principles, norms, standards and procedures for the implementation of democracy through ICT;

- the formation of this institution means a new stage in the development of democratic self-government of society, which requires theoretical comprehension and comprehensive research on the part of legal science; E-democracy should in no way be perceived as a kind of fashion, a tribute to modern views. Its formation is fundamental, objectively demanded by life. Its implementation entails changes in the entire architectonics of power relations, a departure from a simplified understanding of democracy as a simple representation of the majority of the people to the recognition of the importance and value of all forms (including innovative) of citizens' participation in the exercise of public power;

- taking into account the novelty of this institution and the still insufficient level of development of e-democracy in our country, the experience of developed countries in this area (Singapore, Estonia, South Korea, Japan, etc.) should be widely studied and actively introduced into domestic practice;

- it is advisable to develop a Concept for the development of e-democracy, calculated for the long term and assuming a comprehensive systemic development of this institution. The preparation of this document will create a programmatic basis for planning measures in this area, determine goals, objectives and guidelines for further activities, outline ways to achieve them and expected results [15]. It will provide an opportunity in the future to systematically carry out the transition from electronic government (e-government) to electronic government (e-governance), to which the developed countries of the world are striving;

- it is necessary to improve the procedures, methods and tools of e-democracy, to test and implement new interactive forms of exercising democracy in the public administration system;

- it is necessary to use modern high technologies of building a dialogue between the authorities and civil society, to ensure "information transparency" of decision-making by state authorities;

- it is necessary to provide organizational and financial support for public and private Internet projects and other similar initiatives (forums, blogs, Internet conferences, webinars, etc.) in the field of interactive interaction between citizens, authorities and public organizations;

- it is necessary to develop procedures for electronic voting and introduce them into the country's electoral system, to widely apply systems for online identification of voters in elections;

- the development and implementation of electronic public self-government 
procedures in makhallas has great potential; a great advantage of e-democracy is the ability to consolidate and form a consensus opinion based on the results of discussion of significant problems of the population of the region, development on the basis of consensus of recommendations for the authorities;

- the institution in question can significantly improve the quality of identifying unresolved problems in various spheres of life, ensure effective monitoring of their elimination, and quickly inform about the implementation of decisions made with the participation of citizens;

- since e-democracy has enormous potential for improving interaction between the authorities and the population, it is advisable to actively promote its dignity, instill an information culture and disseminate knowledge about the possibilities of ICT in public administration. We support the opinion of specialists who believe that "digital democracy arises as a result of the development of information technologies by citizens, requires a certain level of psychological adaptation of citizens to information innovations, their assimilation of the habits of using information technologies in the process of interacting with power structures" [16]. Therefore, it is necessary to stimulate the training of the general public in the basics of knowledge about the ICT field, publish booklets and videos on the forms and methods of citizens' participation in public administration, prepare appropriate textbooks and manuals.

The model of the state providing public (state) services to its citizens became widespread in developed countries about 20-30 years ago. In Uzbekistan, however, the idea of a state serving the people, the model of a "service state", has been persistently promoted only in recent years. The term "public services" in Uzbekistan began to be actively used in the mainstream of the implementation of administrative reform, the introduction of the so-called positive public administration (management for the provision of public services). As the head of state Sh. Mirziyoyev noted, the main goal of the state is to serve the people, ensure decent living conditions for citizens, improve the quality of life, which fundamentally requires improving the quality and expanding public services [17].

As of February 7, 2020, more than 16.1 million services were provided directly at the Public Service Centers, more than 10.5 million services were provided remotely through the EPTSU portal. At the same time, 178 public services are provided remotely, and this number is constantly increasing [18]. However, even such modest achievements of Uzbekistan in this area, optimization of the system for the provision of public services, had a certain effect - the results of sociological surveys show a significant increase in the level of satisfaction of citizens with the work of government bodies in the provision of services.

\section{Conclusions}

Thus, summing up the analysis, let us conclude that the development of the institution of e-democracy in Uzbekistan is closely linked with the socio-economic, legal, administrative and other reforms being carried out in the country, it requires the development and improvement of the infrastructure of the public administration system and the ICT sphere, active citizenship population, transparency and responsibility of public authorities. Edemocracy, which has arisen as a result of the dynamic development of the information society, is being transformed into a modern system of democratic procedures, rules, 
standards and tools for making power decisions with the widespread use of modern ICTs in the course of the exercise of democracy.

\section{References}

1. Huntington S. The third wave. Democratization at the end of the XX century / Per. from English. M .: "Russian Political Encyclopedia" (ROSSPEN). 2003. - S. 23; Turonok S.G. The Internet and the Political Process // Social Sciences and Modernity. 2001. N 2. S. 55.

2. Ibragimov A.T. Electronic government in the process of formation of electronic democracy // Bulletin of KazNU. 2008.https: //articlekz.com/article/7092 (date of access: 17.09.2019, free access).

3. Recommendation Rec (2004) 15 of the Committee of Ministers of the Council of Europe "On electronic governance" // https://wcd.coe.int / ViewDoc.jsp? Id = 802805 \& Site = CM \& Back ColorInternet = C3C3C3 \& BackColorIntranet = EDB021 \& BackColorLogged = F5D383. (date of access: 17.09.2019, free access mode).

4. It should be noted that there are a number of works devoted to some issues of egovernment activities and citizens' participation in public administration, however, since egovernment and civic participation are only part of the phenomenon of "e-democracy", we can state that there is a gap in the holistic study of this phenomenon.

5. The scientific literature also uses the terms "digital democracy", "cyber democracy", "virtual democracy", "network democracy", etc.

6. Dutton W. Digital democracy: electronic access to politics and services. / In: Dutton W. (eds). Society on the Line. Information Politics in the Digital Age. - Oxford: Oxford University Press, 1999. Riley T.B. Electronic Governance \& Electronic Democracy. Oxford: SFIPublishing, 2000.

7. Antonov Ya.V. Electronic voting in the system of electronic democracy: constitutional and legal research: author. diss. ... ..Cand. jurid. sciences. - M., 2015 .-- S. 3.

8. Grigorieva M.S. Legal definition, essence and content of the concept of "electronic democracy" // Legal Science. 2018, No. 3. - P. 43.

9. Teleshina N.K. The concept and essence of electronic democracy // State and law: theory and practice. 2016. No. 1 (2). - S. 63.

10. Yuldashev A. Updating online public discussion of draft regulations in conditions of free access to them // Law and Life. 2017.No. 232 (10), 233 (11), 234 (12). - S. 24.

11. Recommendations of the Committee of Ministers of the Council of Europe CM / Rec (2009) 1 to the member states of the Council of Europe on electronic democracy // http://krasinskiy.ru/R2009.doc\#1 (date of access: 17.12.2018, free access). access.

12.https: //meningfikrim.uz/ru/pages/about, date of access - 7.02.2020, free

13.https: //pm.gov.uz/ru\#/, access date - 02/07/2020, free access.

14.https: //regulation.gov.uz/ru, access date - 02/07/2020, free access. 
15. As an example, we can cite the "Concept for the development of e-democracy mechanisms in the Russian Federation until 2020" // URL: http://rario.ru/projects/Congress_conception.php. (date of access: 10.01.2020, free access) ...

16. Pashinskaya V.V. Formation of "electronic democracy" in the Russian Federation // Fundamental research. - 2013. - No. 11-6. // http://www.fundamentalresearch.ru/ru/article/view?id=33293 (access date: 10.02.2019, free access).

17. Message from the President of the Republic of Uzbekistan Shavkat Mirziyoyev to Oliy Majlis // Narodnoe Slovo. 2017 December 23.

18. "Statistics" section of the EPIGU website: https://my.gov.uz/ru/site/statisticpage, date of access 7.02.2020, access mode is free. 